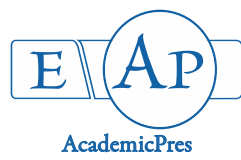

\title{
Study on Gametophytes of Four Species of Maiden Hair Ferns (Adiantum L.) and Their Systematic Implications
}

\author{
Sanatombi Devi YUMKHAM ${ }^{1 *}$, Sumitra SALAM ${ }^{2}$, \\ Sandhyarani D. KHOMDRAM ${ }^{3}$ \\ ${ }^{1}$ Manipur University, Ethnobotany \& Plant Physiology Laboratory, Centre of Advanced Studies in Life Sciences, Canchipur 795003, \\ India; rifle_yumkham@rediffmail.com ('corresponding author) \\ ${ }^{2}$ Nambol L. Sanoi College, Department of Botany, Nambol 795 134, Manipur, India; sumitrasalam@gmail.com \\ ${ }^{3}$ Mizoram University, Department of Botany, Aizawl 796 004, Mizoram, India; sandhyakhomdram@gmail.com
}

\begin{abstract}
Matured spores of four (4) species of maiden hair ferns namely, Adiantum capillus-veneris L., A. caudatum L., $A$. edgeworthii Hook. and $A$. incisum Forssk. were collected and grown in petri-dishes containing natural media formed by mixing dead wood of tree fern (Cyathea Sm.), sand and charcoal powder (2:1:1). The cultures in triplicates for each species were monitored every day from the stage of sowing to the chimera formation. After disintegration of gametophytes, juvenile sporophytes were shifted to pots and morphological characters were studied till the dehiscence of sporangia. Spore germination initiated between 4-6 days for A. capillus-veneris, 7-9 days in A. caudatum and A. incisum and 10-12 days in A. edgeworthii. Prothallia in all the Adiantum are autotrophic, Vittaria type, cordate-shaped, homosporous with antheridia developing earlier than archegonia and remain confined on the adaxial surface. The gametophytes showed considerable variation in their shapes, orientation of lobes, presence or absence of hairs and placement of sex organs on the prothallia. The gametophytic and sporophytic characters are correlated and used in structuring key to species. The study concludes that gametophytic characters also constitute a dependable criterion for assessing their systematics.
\end{abstract}

Keywords: Adiantum; germination; morphology; prothallus; sporophytes; systematics

\section{Introduction}

The maiden hair fern, Adiantum L. (PteridaceaeVittarioideae) is a genus of about 200 species distributed in temperate to tropical regions (Prado et al., 2007). The Adiantum-Vittaroid fern clade accounts about $10 \%$ of extant fern diversity, and therefore plays an important role in the fern flora (Lu et al., 2012). It usually grows in moisture rich shady areas, along water courses, iron rich soil and even in extreme lithophytic condition. According to Mithraja et al. (2012), India harbors 23 species of Adiantum with maximum species diversity occurring in South India and Western Ghats. These ferns are medicinal plants with multiple pharmacological and therapeutic properties. Many alkaloids and bioactive components responsible for their medicinal properties have been isolated and identified (Brahmachari et al., 2003).

The fern gametophyte is an autotrophic, free growing entity with definite form, pattern of growth, structure and reproduction. It forms the tenuous part of the fern life cycle as it determines the sexual strategies and its subsequent role in genetic diversity (Ganguly and Mukopadhyay, 2005). Many research works has been done on the taxonomy, morphology and anatomy of the sporophyte $(2 \mathrm{n})$ of Adiantum, but little is known about the gametophytes which constitute the haploid (n) phase. Prothallus of ferns vary in shape, form and is unique to specific taxon like ribbon-shaped in Hymenophyllaceae, asymmetrical in Anemiacious ferns, tuberous in Ophioglossaceae, cordateshaped in Adiantoids etc. (Banks, 1999). For the first time, Stokey (1951) effectively presented a classical account on gametophyte morphology of ferns and proved beyond doubt that the fern gametophyte, though simple in structure when compared to the sporophyte, affords dependable criteria for taxonomic and phyletic studies. Studying their morphology will not only help to understand their reproductive biology but also enhance their potential to use as a taxonomic parameter. As such, studies on morphology of gametophytes of four species of Adiantum 
456

found in two north eastern states of India, namely Manipur and Nagaland have been undertaken in the present communication. These species include $A$. capillus-veneris L., $A$. caudatum L., $A$. edgeworthii Hook. and $A$. incisum Forssk. Data on prothallia shape and its variation, hairs, lobes orientation and placement of sex organs on the prothallia are critically studied. Overall, the study aims to assess the role of gametophyte in systematics, and finally correlate these characters with morphological parameters of the sporophytic body, and to establish a key to species based on both the haploid and diploid phases.

\section{Materials and Methods}

Mature fertile fronds of the four species of maiden hair ferns (A. capillus-veneris, $A$. caudatum, $A$. edgeworthii and $A$. incisum) were collected from different localities of Manipur and Nagaland states of North East India. Fronds were dried at room temperature in a paper envelope and observed for dehiscence of sporangia using LED-USB Cooling Tech Whole Mount Microscope. Spores were surface sterilized for 10 minutes with $2 \%$ Sodium hypochlorite solution and air dried again for 36 hours. It was then grown in petridishes in triplicates $(\mathrm{A}, \mathrm{B}, \mathrm{C})$ using sterilized natural media formed by mixing Dead Wood of tree fern (Cyathea Sm.), sand and charcoal powder in the ratio of $2: 1: 1$. This is a natural based highly fertile local media and is suitable for growing all types of ferns. All the petri-dishes were kept at a growth chamber $\left(25 \pm 1{ }^{\circ} \mathrm{C}, 2700\right.$ lumens with input voltage of $\left.170-265 \mathrm{~V}\right)$ and watered $(5 \mathrm{ml})$ every alternate day with a sprayer. The cultures were monitored every day from sowing up to the Chimera formation stage. Data of gametophytes were assessed by studying 15 to 25 prothallia for each species. The shape of prothallus, presence/absence of trichomes, variation in lobes and presence of sex organs are critically studied and compared (Table 1 and 2). Young sporophytes with 3-4 juvenile leaves were moved to plastic pots using the same media and all the morphological developments were noted down every 4 days till the dehiscence stage of the sporophytes. The gametophytic characters are correlated with that of sporophytes and a key to species for the four species of Adiantum are constructed. Voucher specimen were prepared and deposited in Manipur University Museum of Plants (MUMP) in duplicates. Microphotographs were taken using phase contrast microscope Motic BA 210 and cameras (Sony DSC-W610 \& Nikon D5300) and highlighted in Figs. 1, 2 and 3.

\section{Results}

\section{Germination of gametophytes}

The spores germinated 4-6 days after sowing in case of A. capillus-veneris, 7-9 days in $A$. caudatum and $A$. incisum, and about 10-12 days in case of $A$. edgeworthii. As soon as the spores landed on the media, water and nutrients are imbibed resulting in bulging of spore wall. First, the spore give rise to two unequal small and large cells. The small cell give rise to rhizoid of gametophyte, while the larger cell form the initial of the filament. The initial developed into 48 cells long filament by transverse division. This is also known as the filamentous stage. With meristematic activity, the anterior region of the filament divides repeatedly in longitudinal manner to form an expanded one celled thick prothallus, which forms the spatulate stage. The apex of the thallus become notched at the meristematic cell and later become symmetrically cordate. With rapid cell divisions, the cordate grows in size and the notch gradually became deeper which also widens the lateral lobes or the wings of the prothallus. At the same time, the rhizoids further developed which are unicellular with size up to $5 \mathrm{~mm}$ long and their number ranging from 9-18. Maximum rhizoids are usually observed in $A$. caudatum (13-18). The whole method of germination and development of gametophyte seen in Adiantum species is termed as Vittaria type (Fig. 3).

\section{Morphology of gametophyte}

In all the four maiden ferns, the mature gametophyte is an autotrophic free living entity with a cordate-shaped (heart-shaped) thallus and shows significant differences in their lobes, shape of the cordate, arrangement of the sex organs and presence/absence of hairs in the prothallus. The longitudinal axis (LA) of the cordate prothallus measuring from posterior rhizoidal portion up to the notch of the thallus in $A$. capillus-veneris is more or less equal to that of the transverse axis (TA) that passes from one lobe to another passing through the notch. However in the latter three species, the cordate assumes more or less oval structure and the TA always exceeded the LA. Prothallus also bears a lot of resemblance among the three species. However, the two wings of the cordate in $A$. caudatum slightly touch one another but never overlap in all the observations. In case of $A$. incisum, the wings often overlaps one another forming a small intersection area, while in $A$. capillus-veneris and $A$. edgeworthii, no overlapping of wings were observed in either a young or a full grown mature gametophytes. The lobes in A. edgeworthii are distantly placed from one another and form a U-shaped gap between the lobes and extend up to the notch. In $A$. caudatum, hairs begin to develop within 25 to 30 days, and around 30-40 days in $A$. incisum. Hairs are unicellular in both the cases, thin-walled, translucent, up to $50 \mu \mathrm{m}$ long and sparsely distributed. Hairs are absent in $A$. capillus-veneris and $A$. edgeworthii. Lateral wings were one cell thick in all the four prothalli, however area around the notch and midrib are several cells thick (Figs. 1, 2).

\section{Development of sex organ}

The antheridia and archegonia in all the four species are borne on the same prothallus (monoecious) and begin to develop within 30-40 days after sowing. The mode of development and structure of the sex organs are alike in all the species. Like many homosporous ferns, the prothallia in Adiantum sp. produce antheridia earlier than the archegonia on abaxial side. The antheridia are developed from a single superficial cell of the prothallus and begin to appear first at the posterior end and near the midrib area gradually extending upwards. It is a simple globose structure comprised of a sterile jacket with a basal stalk and with 32 spermatozoids. In case of $A$. capillus-veneris, the antheridia are distributed throughout the prothallus extending up to the wings, while in the later three species, the antheridia 
Table 1. Comparative account on gametophytes of four species of Adiantum

\begin{tabular}{|c|c|c|c|c|c|}
\hline Species/Voucher specimen & $\begin{array}{l}\text { Size of LA } \\
\text { and TA }\end{array}$ & Nature of lateral wings & Antheridia & Archegonia & Hairs on prothallus \\
\hline $\begin{array}{l}\text { A. capillus-veneris } \\
\text { (Yumkham,0001;MUMP) }\end{array}$ & $\mathrm{TA}=\mathrm{LA}$ & Never overlaps & $\begin{array}{c}\text { Throughout the } \\
\text { prothallus }\end{array}$ & $\begin{array}{c}\text { Around notch } \\
\text { adjoining the midrib on } \\
\text { either side }\end{array}$ & Absent \\
\hline $\begin{array}{c}\text { A. caudatum } \\
\text { (Yumkham,0002;MUMP) }\end{array}$ & $\mathrm{TA}>\mathrm{LA}$ & $\begin{array}{l}\text { Touches one another } \\
\text { without overlapping, } \\
\text { intersection area } \\
\text { absent }\end{array}$ & $\begin{array}{l}\text { Posterior end and near the } \\
\text { midrib of rhizoidal area }\end{array}$ & $\begin{array}{l}\text { Same as } \\
\text { A. capillus-veneris }\end{array}$ & $\begin{array}{l}\text { Present, between } \\
\text { 25-30 days }\end{array}$ \\
\hline $\begin{array}{c}\text { A. edgeworthii } \\
\text { (Yumkham,0003;MUMP) }\end{array}$ & $\mathrm{TA}>\mathrm{LA}$ & $\begin{array}{c}\text { Distant, never } \\
\text { overlaps, forms U- } \\
\text { shaped gap between } \\
\text { the lobes }\end{array}$ & $\begin{array}{c}\text { Same as } \\
\text { A. caudatum }\end{array}$ & $\begin{array}{c}\text { Same as } \\
\text { A. capillus-veneris }\end{array}$ & Absent \\
\hline $\begin{array}{c}\text { A. incisum } \\
\text { (Yumkham,0006;MUMP) }\end{array}$ & $\mathrm{TA}>\mathrm{LA}$ & $\begin{array}{c}\text { Overlapping, } \\
\text { intersection area } \\
\text { present }\end{array}$ & $\begin{array}{c}\text { Same as } \\
\text { A. caudatum }\end{array}$ & $\begin{array}{l}\text { Arranged in distinct } \\
\text { longitudinal rows near } \\
\text { the notch }\end{array}$ & $\begin{array}{c}\text { Present, between } 30- \\
40 \text { days }\end{array}$ \\
\hline
\end{tabular}

Table 2. Stages of gametophyte development in Adiantum species from the day of sowing to of spore dehiscence stage in sporophytes

\begin{tabular}{cc}
\hline Days & Signs of development \\
\hline 0 & Sowing of spores in media \\
$4-6$ & Germination in $A$. capillus-veneris \\
$7-9$ & Germination in $A$. caudatum and $A$. incisum \\
$10-12$ & Germination in $A$. edgeworthii \\
$7-20$ & Cordate-shaped prothallus, hairs begin to appear on prothallus in $A$. caudatum \& $A$. incisum, full development of one celled \\
$21-30$ & parenchymatous tissue \\
$31-40$ & Sex organs-antheridia and archegonia developed, further maturation of sex organs \\
$41-49$ & Fertilization, zygote formation \\
$50-70$ & Fronds show maturation, green indusia developed on margin of pinna, sori turning brown, dehiscence \& released of sori \\
\hline After 70 & Young sporophyte transferred to green house \\
After 120-140 &
\end{tabular}

remain confined towards the posterior end and around the midrib of the rhizoidal area. The archegonia usually developed around the notch of the prothallus adjoining the midrib on either side in all the species except in $A$. incisum where the archegonia are arranged in distinct longitudinal rows around the notch. Each archegonium projects from the surface of prothallus and forms a flask-shaped structure. It consists of a swollen base containing the ventral canal cell with egg cell and a projecting slender neck. The ventral canal cell remains embedded within the prothallia tissues, while the neck protrudes outwards.

\section{Fertilization and embryo development}

Fertilization occurs only when the sex organs come in contact with water. Sperms swim towards the archegonial neck and enter the venter finally reaching the egg. The male nucleus fused together with the egg thus accomplishing fertilization and forms a zygote. Two unequal cells-smaller epibasal and larger hypobasal cells are formed by longitudinal division. At this stage, the archegonial neck cells formed 2-4 layered calyptra which is protective in function till the emergence of first leaf and root. After repeated divisions, a 32 celled embryo is formed and differentiation of frond, stem and root begins to take place. The basal cells formed the foot region, which later develop to absorptive organ (rhizoids). The epibasal cells formed the first primordial leaf and takes around 60-70 days for development of young sporophytes with 2-3 juvenile leaves. The parenchymatous cells and veins begin to develop in the leaves. At this point, the Chimera of sporophyte and gametophyte are seen growing together and later the gametophyte begin to disintegrate.

\section{Development of sporophyte}

After the disintegration of the gametophyte, the juvenile sporophyte started developing more erect fronds. Brown scales begin to appear at the basal stipe region and the rhizome. More young fronds in circinate vernation begin to emerge out from the rhizome and pinnae shows profuse growth with maturation. After 120 days, a full grown mature sporophyte begin to produce sori protected by green indusia at first, and later on turning brown at maturity. A brief account on the morphology of sporophytes of the four species is highlighted in Table 3 below. 
Table 3. Comparative morphology of the four species of Adiantum

\begin{tabular}{|c|c|c|c|c|}
\hline Character & A. capillus-veneris & A. caudatum & A. edgeworthii & A. incisum \\
\hline Rhizome & Creeping & Erect & Erect & Erect \\
\hline Stipe & $(5-20) \mathrm{cm}$ long, scaly, glabrous & $\begin{array}{l}\text { (5-12) cm long, scaly, } \\
\text { pubescent }\end{array}$ & $\begin{array}{c}(7-15) \text { cm long, glossy, } \\
\text { glabrous }\end{array}$ & $\begin{array}{c}(8-17) \mathrm{cm} \text { long, dense } \\
\text { hairs present }\end{array}$ \\
\hline Fronds & $\begin{array}{l}\text { Bipinnate, }(6-15 \times 5-8) \mathrm{cm} \text {, } \\
\text { alternate, } 3-5 \text { on each side, } \\
\text { flabellate, lobes finely dentate, } \\
\text { both surface glabrous }\end{array}$ & $\begin{array}{l}\text { Unipinnate, }(10-30 \times 2-3) \mathrm{cm} \text {, } \\
\text { alternate, } 10-30 \text { on each side, } \\
\text { incised into } 3-6 \text { lobes, both } \\
\text { surfaces hairy }\end{array}$ & $\begin{array}{l}\text { Unipinnate, }(7-24 \times 2-3) \mathrm{cm} \text {, } \\
\text { opposite-alternate, } 8-25 \text { on } \\
\text { each side, } 2-5 \text { lobed, glabrous, } \\
\text { red pigmentation when } \\
\text { young }\end{array}$ & $\begin{array}{c}\text { Unipinnate, }(10-40 \times 2-3) \\
\mathrm{cm} \text {, alternate, } 7-20 \text { on each } \\
\text { side, } 2-4 \text { lobed, both } \\
\text { surfaces hairy }\end{array}$ \\
\hline Vegetative buds & Absent & Present & Present & Present \\
\hline Sori & $\begin{array}{l}\text { Orbicular-reniform, } 4-9 \text { per } \\
\text { pinna }\end{array}$ & $\begin{array}{c}\text { Orbicular-oblong, } 8-17 \text { per } \\
\text { pinna }\end{array}$ & $\begin{array}{l}\text { Orbicular-oblong 4-6 per } \\
\text { pinna }\end{array}$ & $\begin{array}{l}\text { Oblong-lunate, } 4-8 \text { per } \\
\text { pinna }\end{array}$ \\
\hline Fertile period & Throughout the year & August-September & October-February & November-April \\
\hline Spore size \& Ornamentation & $(42 \times 57) \mu \mathrm{m}$, granulose & $(39 \times 44) \mu \mathrm{m}$, verrucate & $(32 \times 35) \mu \mathrm{m}$, faintly granulose & $\begin{array}{c}(35 \times 40) \mu \mathrm{m} \text {, densely } \\
\text { verrucate }\end{array}$ \\
\hline
\end{tabular}
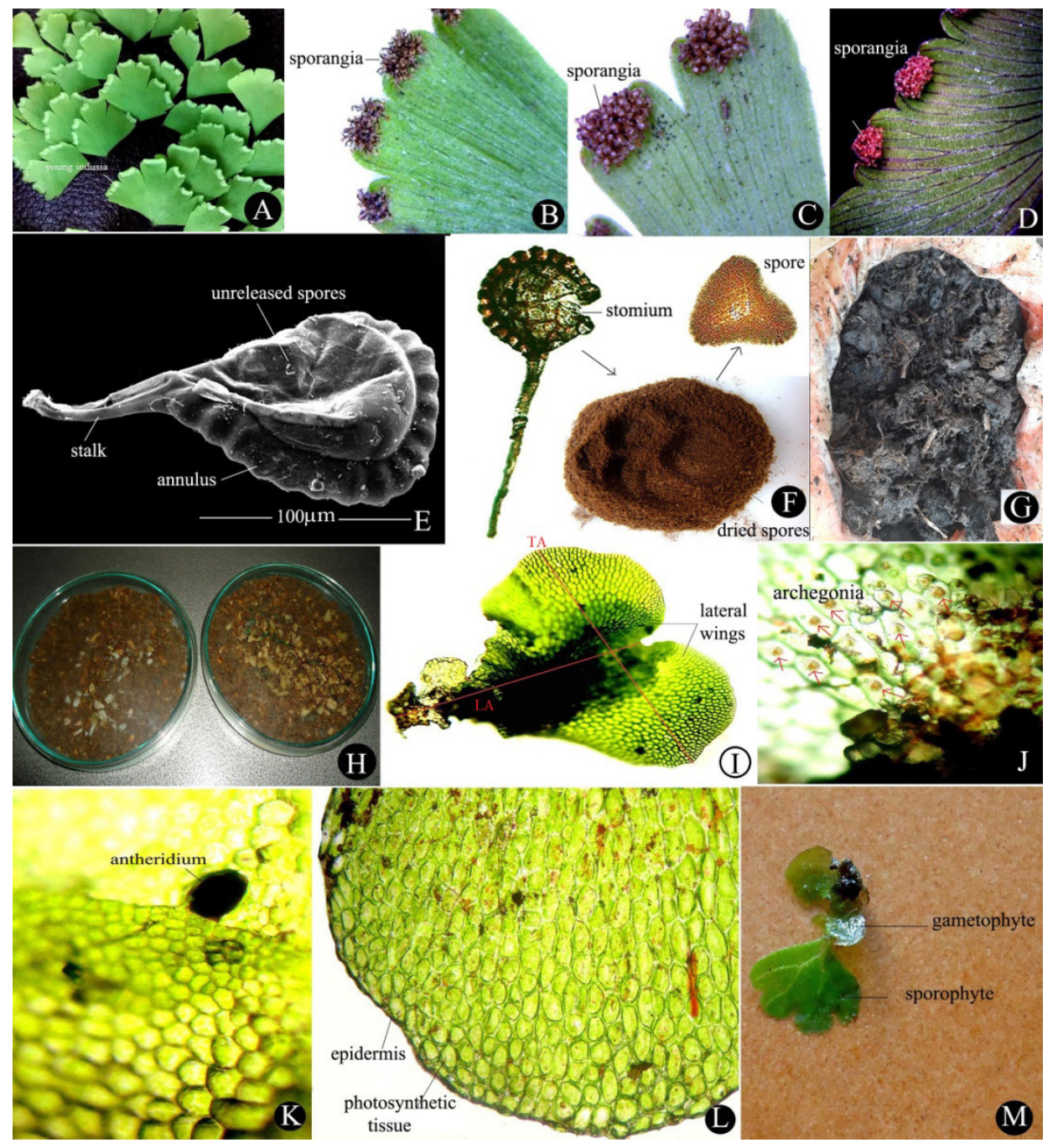

Fig. 1. Sporophytic and gametophytic features in Adiantum. (A) Fertile frond in A. capillus-veneris (B) Pinna of A. caudatum (C) Pinna of A. incisum (D) Pinna of A. edgeworthii (E) Sporangium in A. capillus-veneris before dehiscence (F) Typical sporangium in Adiantum for dehiscence with stomium, dried spores and a single spore (G) Dead Wood of Tree Fern (H) Petridish with media for spore sowing (I-K) Prothallus of $A$. capillus-veneris with sex organs-archegonia $\&$ antheridia (L-M) One celled thick parenchymatous cells in gametophyte \& chimera of sporophyte and gametophyte in $A$. capillus-veneris 

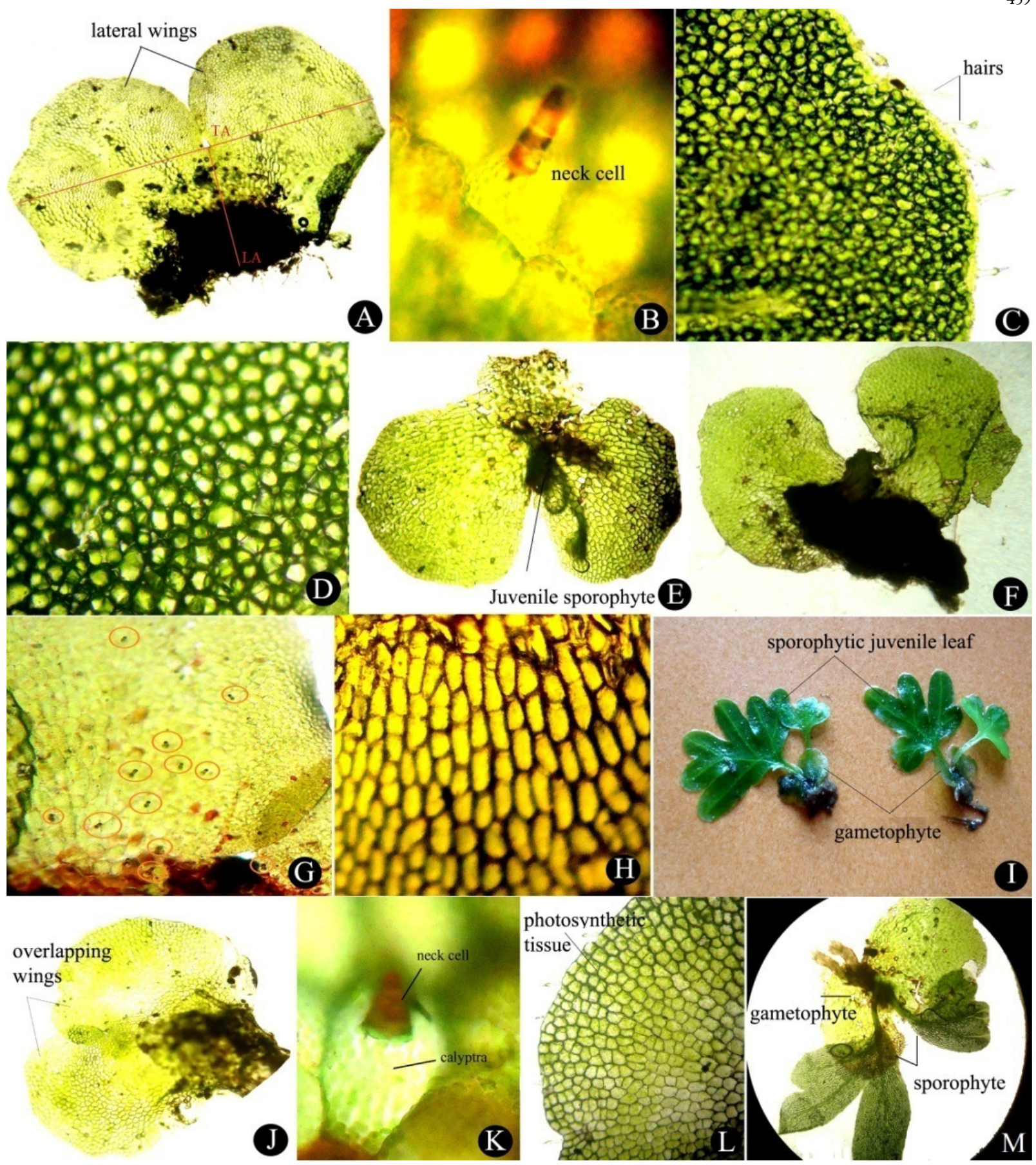

Fig. 2. (A-B) Prothallus in A. caudatum and archegonia (C-D) Development of trichomes on prothallus \& parenchymatous cells (E) Development of juvenile sporophyte on prothallus (F-G) Prothallus of $A$. edgeworthii \& archegonia distributed near the notch (H-I) Parenchymatous cell of prothallus of $A$. edgeworthii before degradation \& chimera formation (J-M) Prothallus of $A$. incisum with overlapping wings forming eclipse, archegonium with developed calyptra, parenchymatous cells \& sporophyte development on prothallus 


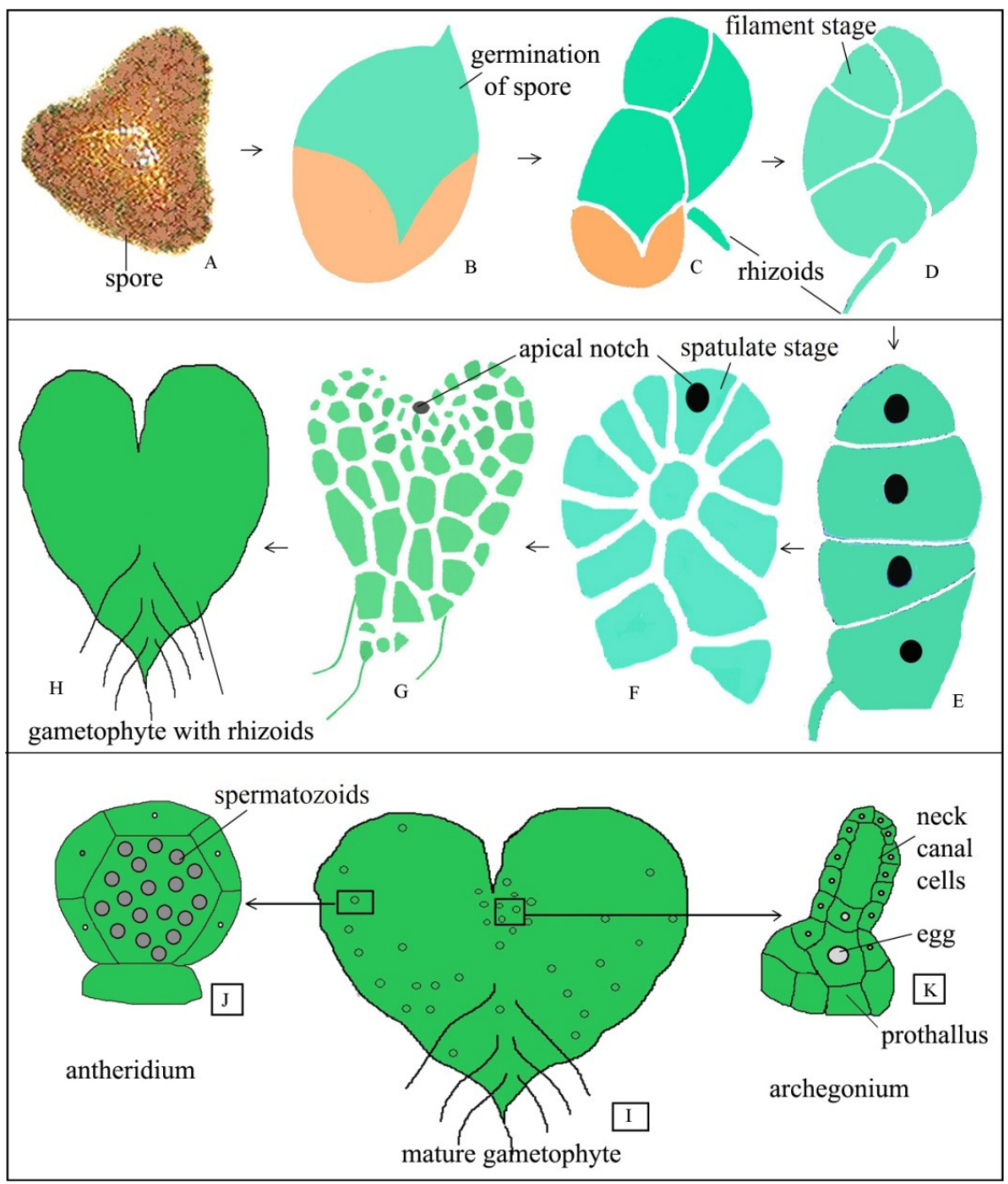

Fig. 3 Diagrammatic representation depicting stages of gametophyte formation (Adiantum sp.) from spore germination to prothallus formation with sex organs

\section{Dehiscence of sporangium and spores}

The average size of sporangium in Adiantum is (110$130 \times 50-80) \mu \mathrm{m}$. With dehydration and maturation of sporangia, indusial flaps tear off from the pinnae, thus exposing a bunch of sporangia. Within a single sporangium, 64 spores are produced and get released into the air through the stomium. Spores are trilete, tetrahedral in shape and exine ornamentation ranges from granulose (A. capillusveneris, $A$. edgeworthii) to verrucate (A. caudatum, $A$. incisum) structures.

\section{Discussion}

During the course of the experiment, we have studied the germination of spores, stages of gametophyte development and formation of sporophytes in the four species of maiden ferns (A. capillus-veneris, A. edgeworthii, $A$. caudatum, $A$. incisum) found in two states of India (Manipur \& Nagaland). For germination, natural media formed by mixing dead wood of tree fern, sand and charcoal powder in the ratio of 2:1:1 were used (Fig. 1G, H). The entire life cycle of Adiantum completes within 120 to 140 days. Germination of spores usually takes place within 4-12 days. Gametophytes in all the four species are cordateshaped and show visible variation in their shape, nature of overlapping in lateral wings and in the size of transverse axis (TA) by longitudinal axis (LA). Spore germination in Adiantum is Vittaria type which is the commonest type of polar germination (Nayar and Kaur, 1971; Raghavan, 1989). Characters of mature gametophytes are phylogenetically significant and remain consistent among species within a genus and often among genera within a family (Stokey, 1960). They possess evolutionarily conservative morphological characters like patterns of spore germination, development and form of prothallus, origin of hairs, cellular structure of gametangia etc. and are useful in phylogenetic reconstruction (Farrar, 2003). Distribution of antheridia, archegonia and hairs also played an important role in differentiating the four gametophytes. According to Nayar (1962), the prothallus bears only one sporophyte but two or more sporophytes may sometimes develop under cultural condition. However during the study, we never come across a prothallus bearing multiple gametophytes. 
This may be due to the selection of media derived from natural ingredients which is very much similar to natural habitat. After 70 days, juvenile sporophytes are transferred to green house. The sporophytes show diverse in morphology, anatomy and growth just after the Chimera formation, and within few days exhibit their true identity.

\section{Conclusions}

The morphology of gametophytes played a very important role in assigning a systematic position in ferns (Khoo and Thomas, 1980). We know that the net result of spore germination is the prothallus and shows variation in shape, structure, presence/absence of hairs and pattern of sex organ distribution. Literature on Adiantum systematics show that main criterion of key construction is primarily based on sporophytic characters only. In the present study, we concluded that the gametophytes are also one of the most reliable taxonomic parameters in spite of their microscopic size and can be incorporated in taxonomic keys. A correlation between the two phases of life cycle (gametophyte \& sporophyte) will help us understand more on ferns systematic at species and even at interspecific level.

\section{Acknowledgements}

This work was supported by Science \& Engineering Board (SERB), New Delhi, India (Grant No. SB/YS/LS138/2014). Thanks are due to all locals of Mao (Manipur) \& Wakha (Nagaland) who assisted us while collecting specimens.

\section{Conflict of Interest}

The authors declare that there are no conflicts of interest related to this article.

\section{References}

Banks J (1999). Gametophyte development in ferns. Annual Review of Plant Physiology and Plant Molecular Biology 50(1):163-186.

Brahmachari G, Mondal S, Chatterjee D, Brahmachari K (2003). Phytochemicals and biological activities of Adiantum species. Journal of Science and Industrial Resources 62:1119-113.
Farrar DR (2003). Gametophyte morphology and breeding systems in ferns. In: ChandraS, Srivastava M(Eds). Pteridology in the New Millennium. Springer,Dordrecht.

Ganguly G, Mukhopadhyay R (2005). In vitro study on gametophyte development of Hypolepis alpine (Bl.) Hook. Phytomorpology 55(34):179-184.

Khoo S, Thomas M (1980). Studies on the germination of fern spores. The Plant Propagator 26(2):11-15.

Lu JM, Wen J, Lutz S, Wang YP, Li DZ (2012). Phylogenetic relationships of Chinese Adiantum based on five plastid markers. Journal of Plant Sciences 125(2):1-13.

Mithraja MJ, Antonisamy JM, Mahesh M (2012). Inter-specific variation studies on the phyto-constituents of Christella and Adiantum using phytochemical methods. Asia Pacific Journal of Tropical Biomedicine 2(1):S40-S45.

Nayar BK (1962). Studies in Pteridaceae. V. Contributions to the morphology of some species of maidenhair ferns. Botanical Journal of Linnaean Society 58(372):185-199.

Nayar BK, Kaur S (1971). Gametophytes of homosporous ferns. The Botanical Review37(3):296-380.

Prado J, Rodrigues CN, Salatino A, Salatino ML (2007). Phylogenetic relationships among Pteridaceae, including Brazilian species, inferred from rbcL sequences. Taxon 56(2):355-368.

Raghavan V (1989). Developmental biology of fern gametophytes. Cambridge University Press, Cambridge, pp 361.

Stokey AG (1951). The contribution by the gametophyte to the classification of the homosporous ferns. Phytomorphology 1(1-2):3958.

Stokey AG (1960). Multicellular and branched hairs on the fern gametophyte. American Fern Journal 50(1):78-87. 